\title{
Redox chemistry of molybdenum in natural waters and its involvement in biological evolution
}

\section{Deli Wang*}

State Key Laboratory of Marine Environmental Science, Xiamen University, Xiamen, China

\section{Edited by:}

Sergio Sanudo-Wilhelmy, University

of Southern California, USA

Reviewed by:

Kathleen Scott, University of South

Florida, USA

Zongze Shao, State Oceanic

Administration, China

*Correspondence:

Deli Wang, State Key Laboratory of Marine Environmental Science,

Xiamen University, 422 Siming Nanlu, Xiamen 361005, China.

e-mail: deliwang@xmu.edu.cn

\begin{abstract}
The transition element molybdenum (Mo) possesses diverse valances $(+\mathrm{II}$ to $+\mathrm{VI})$, and is involved in forming cofactors in more than 60 enzymes in biology. Redox switching of the element in these enzymes catalyzes a series of metabolic reactions in both prokaryotes and eukaryotes, and the element therefore plays a fundamental role in the global carbon, nitrogen, and sulfur cycling. In the present oxygenated waters, oxidized Mo(VI) predominates thermodynamically, whilst reduced Mo species are mainly confined within specific niches including cytoplasm. Only recently has the reduced $\mathrm{Mo}(\mathrm{V})$ been separated from $\mathrm{Mo}(\mathrm{VI})$ in sulfidic mats and even in some reducing waters. Given the presence of reduced $\mathrm{Mo}(\mathrm{V})$ in contemporary anaerobic habitats, it seems that reduced Mo species were present in the ancient reducing ocean (probably under both ferruginous and sulfidic conditions), prompting the involvement of Mo in enzymes including nitrogenase and nitrate reductase. During the global transition to oxic conditions, reduced Mo species were constrained to specific anaerobic habitats, and efficient uptake systems of oxidized Mo(VI) became a selective advantage for current prokaryotic and eukaryotic cells. Some prokaryotes are still able to directly utilize reduced Mo if any exists in ambient environments. In total, this mini-review describes the redox chemistry and biogeochemistry of Mo over the Earth's history.
\end{abstract}

Keywords: molybdenum, redox speciation, enzymes, ancient ocean, biological evolution

\section{INTRODUCTION}

Only a few transition elements (e.g., Fe, Mo, and $\mathrm{Cu}$ ) were selected in the evolution of life and play a fundamental role in the global cycling of carbon, nitrogen, and sulfur (e.g., Kisker et al., 1999; Bittner and Mendel, 2010). Molybdenum (Mo) is an essential trace element for archea, bacteria, and eukaryotes (e.g., Williams and Fraústo da Silva, 2002; Zhang and Gladyshev, 2008; Hernandez et al., 2009). More than 60 metalloenzymes and proteins have been identified containing Mo (Lippard et al., 1994; Hille, 1996; Kisker et al., 1997; Stiefel, 1997, 1998; Kroneck and Abt, 2002; Boll et al., 2005; NC-IUB, 2012; ExPASy, 2012), including nitrogenase and nitrate reductase, which tie the element to the nitrogen cycle (e.g., Kroneck and Abt, 2002).

Although Mo is relatively scare in the Earth's crust (1.1 ppm, Wedepohl, 1995), it is more available to biological processes than many other abundant metals in the crust (e.g., Al of $7.96 \%, \mathrm{Sr}$ of $333 \mathrm{ppm}$, and $\mathrm{Ti}$ of 4,010 ppm; Wedepohl, 1995) based on water concentrations. The total dissolved Mo concentrations are relatively low in river waters ( $\sim 5 \mathrm{nM}$; Martin and Meyback, 1979), whereas this trace element is the most abundant transition metal in the oxygenated ocean (dissolved Mo: 105 nM; Collier, 1985). Generally, those low-level trace elements such as Fe may potentially limit the growth of phytoplankton in the ocean, and particularly in the high nutrients and low chlorophyll $a$ areas (e.g., Martin and Fitzwater, 1988; Boyd et al., 2000). Mo deficiency is not common in natural environments, and it did, however, occur for many terrestrial plants (e.g., Hewitt and Bolle-Jones, 1952; Gupta, 1997; Kaiser et al., 2005), and even for freshwater phytoplankton (Dumont, 1972; Romero et al., 2011; Glass et al., 2012). Recently,
Barron et al. (2009) reported that lack of Mo may limit atmospheric $\mathrm{N}_{2}$ fixation in tropical forests with highly weathered acidic soils. Glass et al. (2010) further demonstrated that extremely low Mo levels $(<1 \mathrm{nmol} / \mathrm{L})$ can induce $\mathrm{N}$-limitation for freshwater and coastal filamentous heterocystous cyanobacteria. Indeed, the unavailability of Mo has been long observed as limiting $\mathrm{N}_{2}$ fixation or nitrate assimilation in coastal waters (e.g., Brattberg, 1977). Howarth and Cole (1985) hypothesized that high levels of sulfate in seawater might competitively inhibit algal Mo uptake in coastal waters.

In enclosed basins, e.g., the Cariaco Trench, the Black Sea, and the Saanich Inlet, Mo may be depleted with concentrations of as low as $3 \mathrm{nmol} / \mathrm{L}$, whereas the sediments there accumulated Mo as high as $140 \mu \mathrm{g} / \mathrm{g}$ (Berrang and Grill, 1974; Emerson and Huested, 1991). It seems that total dissolved Mo concentrations in the ancient reducing ocean might be similarly low (e.g., $\sim 10 \%$ of the present oceanic levels, Anbar and Knoll, 2002). Furthermore, reduced Mo probably existed in the ancient reducing ocean too. This mini review summarizes the recent advances regarding the redox chemistry of Mo in natural waters. The biological involvements of reduced Mo over the Earth's history are discussed.

\section{REDOX SPECIATION OF Mo IN NATURAL WATERS}

The transition element Mo possesses a wide range of different redox species $(+\mathrm{II}$ to $+\mathrm{VI})$. Under the current atmospheric $\mathrm{pO}_{2}$ of $0.2 \mathrm{~atm}$, molybdate ions (e.g., $\mathrm{MoO}_{4}^{2-}$ and $\mathrm{HMoO}_{4}^{-}$) are the most abundant chemical forms of Mo in oxygenated freshwater and seawater systems, whilst reduced $\mathrm{Mo}(\mathrm{V})$, likely as $\mathrm{MoO}_{2}^{+}$, $\mathrm{MoO}_{3}^{+}$, and $\mathrm{Mo}_{2} \mathrm{O}_{4}^{2+}$ (e.g., Szilágyi, 1967; Loach, 1970; Bertine, 
1972; Coughlan, 1980), are expected to coexist in reducing environments (Brookins, 1988). Under strongly reducing conditions, Mo is expected to be further reduced to its less soluble forms (e.g., $\mathrm{MoO}_{2}$ and $\mathrm{MoS}_{2}$ ). As $\mathrm{Mo}$ (II) and $\mathrm{Mo}$ (III) have never been reported in the aquatic systems (e.g., Mendel, 2005), their natural occurrences will not be discussed here.

The $\mathrm{O}$ atoms in $\mathrm{MoO}_{4}^{2-}$ may be replaced by $\mathrm{S}$ in the presence of $\mathrm{HS}^{-}$, creating a series of thiomolybdate complexes (Helz et al., 1996). Mo in these compounds can be further reduced to Mo(IV) and $\mathrm{Mo}(\mathrm{V})$, forming a series of sulfido species (Miller et al., 1980; Vorlicek and Helz, 2002). Wang et al. (2009), using a new technique for separating $\mathrm{Mo}(\mathrm{V})$ from $\mathrm{Mo}(\mathrm{VI})$ in natural waters, quantified the $\mathrm{Mo}(\mathrm{V})$ levels in sulfidic microbial mats and even in some reducing waters (Wang et al., 2009, 2011). As a significant transient intermediate during reductive diagenesis, reduced $\mathrm{Mo}(\mathrm{V})$ can be present in specific niches, e.g., in reducing porewater. Indeed, $\mathrm{Mo}(\mathrm{V})$ might range from $5-20 \mathrm{nM}$, accounting for up to $\sim 20 \%$ of $\Sigma$ Mo under low-sulfide conditions ( $<100 \mu \mathrm{mol} / \mathrm{L}$; Wang et al., 2011). $\mathrm{Mo}(\mathrm{V})$ may be further reduced to $\mathrm{Mo}(\mathrm{IV})$, as in $\mathrm{MoS}_{2}$ under strongly sulfidic conditions $\left(\mathrm{HS}^{-}>100 \mu \mathrm{mol} / \mathrm{L}\right.$; Wang et al., 2011).

In the present ocean, the redox switching of Mo can only occur in specific niches under bacterial mediation. For example, Mo(VI) can be reduced to the intermediate state of $\mathrm{Mo}(\mathrm{V})$, and the reduced state of $\mathrm{Mo}(\mathrm{IV})$ as molybdenite $\left[\mathrm{MoS}_{2}(\mathrm{~s})\right]$ by sulfate-reducing bacteria in the presence of sulfide (e.g., Tucker et al., 1997, 1998; Biswas et al., 2009). Some microorganisms can also oxidize the reduced Mo (e.g., Sugio et al., 1992), and, indeed, reduced Mo can serve as the electron donor to sustain autotrophic growth (e.g., Lyalikova and Lebedeva, 1984). In particular, Mo(V) may be produced from bio-oxidization of mineral molybdenite $\left(\mathrm{MoS}_{2}\right.$; e.g., Brierley, 1974). Once produced, the reduced $\mathrm{Mo}(\mathrm{V})$ may be complexed and stabilized with organic ligands naturally for a long while (Szilágyi, 1967; Bertine, 1972).

The existence of reduced $\mathrm{Mo}(\mathrm{V})$ was proposed later on as a potential limiting factor for cyanobacterial productivity in coastal and oceanic surface waters (Howarth and Cole, 1985; Yamazaki and Gohda, 1990). Griffin (1975) pointed out that nitrogenase in nitrogen fixers will not be active unless a trace amount of $\mathrm{Mo}(\mathrm{V})$ complexes is present. Howarth and Cole (1985) speculated that molybdate might be reduced extracellularly, and the reduced $\mathrm{Mo}(\mathrm{V})$, instead of the total, might be responsible for cyanobacterial blooms. Indeed, specific niches like anoxic microzones widely exist in the present oxygenated ocean due to cellular exudation of reduced substances and organic colloids (e.g., Carpenter and Price, 1976; Bryceson and Fay, 1981; Paerl and Bland, 1982; Paerl, 1985; Paerl and Prufert, 1987; Ploug et al., 1997). The diazotrophic cyanobacteria Trichodesmium could also form anoxic microzones by aggregating together. Inside these anoxic microzomes, the reduced $\mathrm{Mo}(\mathrm{V})$ was produced and actively involved in $\mathrm{N}_{2}$ fixation (Howarth and Cole, 1985; Paerl, 1985; Paerl et al., 1987).

\section{BIOLOGICAL UPTAKE AND ASSOCIATED REDOX CHANGES OF Mo IN CELLS}

In contrast to its higher abundance in the present ocean $(105 \mathrm{nM}$; Collier, 1985), the biological requirement of Mo is relatively lower than many other essential elements including $\mathrm{Fe}$ and $\mathrm{Cu}$ (e.g., Finkel et al., 2006). The molar Mo/Fe ratio is only 0.03 in bacteria (Barton et al., 2007), and 0.005 in some eukaryotic phytoplankton (Ho et al., 2003). Such a relatively lower requirement of the element may be attributable to the limited numbers of Mo containing enzymes in biology (e.g., Zerkle et al., 2005; Finkel et al., 2006), though these are essential to basic biological processes (e.g., nitrogen metabolism).

Until now, both less-specific and high-affinity molybdate uptake systems have been identified in biology (Figure 1). Previous work has confirmed that current prokaryotic and eukaryotic cells possess efficient uptake systems to utilize this element (e.g., high-affinity molybdate transporter; Tejada-Jimenez et al., 2007; Tomatsu et al., 2007; Baxter et al., 2008; Bittner and Mendel, 2010) including $\mathrm{ABC}$ transporter. Eukaryotic molybdate transport might involve more complex systems. In contrast, less-specific uptake of oxidized Mo widely exists in the present prokaryotic and eukaryotic cells, which utilizes other anion transporters: phosphate (Heuwinkel et al., 1992) or sulfate transporters (Tweedie and Segel, 1970; Marschner, 1995). Work has further shown an alternative: some soil bacteria are able to excrete siderophores (aminochelin) to complex extracellular Mo, and utilize trace amount of the element from ambient environments (Liermann et al., 2005).

Once inside cells, Mo cofactors are synthesized, and then allocated to the appropriate apo-enzymes via carrier proteins (Aguilar et al., 1992; Figure 1). These cofactors can be chaperoned to target proteins, into which they are inserted by specific trafficking proteins in prokaryotes (e.g., Ba et al., 2009; Mendel and Schwarz, 2011). Pau and Lawson (2002) reported that some bacteria possess specific molybdate-binding protein with a capacity of storing up to eight molybdate oxyanions for later use by the cells. As Mo in enzymes is extremely sensitive to intracellular oxidations such as reactive oxo species (Rajagopalan and Johnson, 1992), it is well protected within the storage proteins (e.g., Massey et al., 1970; Aguilar et al., 1992; Ichimori et al., 1999; Fenske et al., 2005; Schemberg et al., 2008; Hernandez et al., 2009; Figure 1). With the protection, Mo can easily switch redox states, and be actively involved in transferring electron/proton and even oxygen (e.g., Swedo and Enemark, 1979).

The Mo enzymes generally include two types of cofactors on the basis of the structure: Mo-co and Fe-Mo-co. Fe-Mo-co is a unique poly-metallic compound $\left(\mathrm{MoFe}_{7} \mathrm{~S}_{6}\right)$, which has been found only in Mo nitrogenase (e.g., Howard and Rees, 1996; Einsle et al., 2002). Two alternative nitrogenases (Fe and V) will not be discussed here. Mo nitrogenase catalyzes the ATP-dependent reduction of atmospheric dinitrogen to bioavailable ammonia, which represents the key point of entry of reduced nitrogen into the food chain (Burris, 1991; Burgess and Lowe, 1996; Hu et al., 2008). In the catalytic reaction, the $\mathrm{N} \equiv \mathrm{N}$ triple bond is broken and therefore $\mathrm{N}_{2}$ is being reduced at a sterically protected, single Mo center (Fe-Mo-co; Yandulov and Schrock, 2003). Mo-co is a mononuclear Mo atom coordinated to the sulfur atoms of a pterin. The task of the pterin is to position the catalytic Mo atom correctly within the active center, to control its redox behavior, and to participate in the electron transfer to and from the Mo atom (Mendel and Bittner, 2006). Mo-co containing enzymes are ubiquitous in archae, bacteria, and eukaryotes (Williams and Fraústo da Silva, 2002; Zhang and 


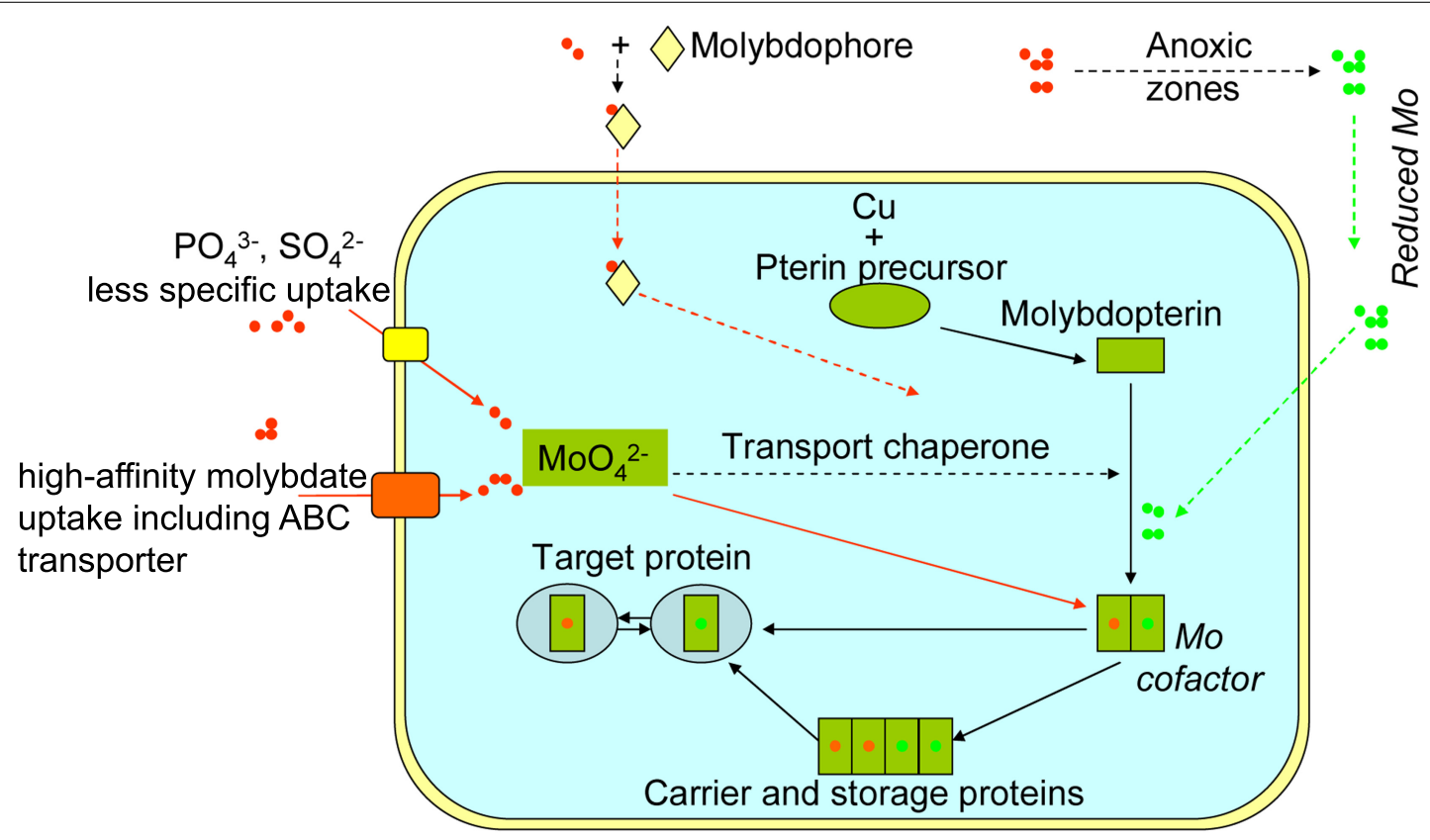

FIGURE 1 | Schematics of Mo uptake and storage in prokaryotic and eukaryotic cells. Routes represented by dashed lines were only identified in prokaryotes, while routes represented by solid lines occurred in both current prokaryotes and eukaryotes. Green dots refer to reduced Mo species, and red dots refer to oxidized Mo (molybdate).

Gladyshev, 2008; Hernandez et al., 2009), including four families: xanthine oxidase, aldehyde oxidoreductase, sulfite oxidase, and dimethylsulfoxide reductase. This mini review will only discuss a few Mo-co-containing enzymes critical in the cycling of sulfur and nitrogen. Among them, sulfite oxidase catalyzes the conversion of sulfite to sulfate, which is the terminal step in the metabolism of sulfur-containing compounds (e.g., cysteine and methionine) in bacteria, plants, and mammals (Cramer et al., 1979). Polysulfide reductase, another group of Mo-containing enzymes, converts polysulfide (as sulfur) to $\mathrm{H}_{2} \mathrm{~S}$ (Stiefel, 1993). Nitrate reductase catalyzes the first step of nitrate reduction during nitrate assimilation for all autotrophs including higher plants and algae (e.g., Eppley et al., 1969; Butler et al., 1999; Campbell, 1999; Morozkina and Zvyagilskaya, 2007).

Mo may exist in several different redox states in these enzymes: e.g., oxidized $\mathrm{Mo}(\mathrm{VI})$, intermediate $\mathrm{Mo}(\mathrm{V})$, and reduced $\mathrm{Mo}(\mathrm{IV})$ forms. Two electron transfer or one oxygen transfer reactions are coupled with $\mathrm{Mo}(\mathrm{IV})$ oxidation to $\mathrm{Mo}(\mathrm{VI})$, and the active $\mathrm{Mo}(\mathrm{IV})$ state is regenerated by two subsequent one-electron transfer reactions through the intermediate $\mathrm{Mo}(\mathrm{V})$ state (Kisker et al., 1997). Those one-electron transfer reactions are carried out by switching the redox pairs: $\mathrm{Mo}(\mathrm{IV}) /(\mathrm{V})$ or $\mathrm{Mo}(\mathrm{V}) /(\mathrm{VI})$. The intermediate $\mathrm{Mo}(\mathrm{V})$ can act as an interface between one- and two-electron redox reactions, and catalyzes a variety of reactions using water or $\mathrm{H}_{2} \mathrm{~S}$ as the electron donor (Hille, 1999, 2002). Mo(V) is generally produced from Mo(IV) by transferring a reducing equivalent or from $\mathrm{Mo}(\mathrm{VI})$ by accepting an electron (e.g., Barber et al., 1987). Hence, Mo(V) levels in cells could account for as high as $50 \%$ of the total intracellular Mo (Hille and Massey, 1985).

\section{INVOLVEMENT OF REDOX SPECIATION OF MO IN THE EVOLUTION OF LIFE}

In the present oxygenated ocean, reduced Mo species have only been confined to specific niches including cytoplasm (e.g., Hille and Massey, 1985), sulfidic mats, and some reducing waters (Wang et al., 2009, 2011). These reduced Mo species might, however, be abundant in the ancient reducing ocean, e.g., in the ferruginous Archaean and the sulfidic Proterozoic (Figure 2). The existences of diverse Mo redox species probably facilitated the emergences of Mo enzymes (or prototypes) catalyzing metabolic reactions in the cycling of carbon, nitrogen, and sulfur, and finally the evolution of bacteria and eukaryotes, which possess Mo enzymes (Figure 2).

The Archaean ocean $(3.5 \sim 2.2$ billions years ago) was generally characterized by reduced species including $\mathrm{NH}_{4}^{+}, \mathrm{Fe}(\mathrm{II})$, and a small amount of HS $^{-}$(Zerkle et al., 2005; Fani and Fondi, 2009). At this stage, Mo was mostly released from volcanoes and/or hydrothermal vents (Nisbet, 2000). Different redox species (IV, V, and VI) probably coexisted together under such reducing conditions. $\mathrm{MoS}_{2}$ has an extremely low solubility in aqueous solutions (Ksp $=10^{-43}$, Garrels and Christ, 1965), and $\mathrm{MoS}_{4}^{2-}$ is easily adsorbed onto mineral particles and organic materials (Helz et al., 1996). Both processes resulted in low levels of the total dissolved Mo, and instead increased the proportion of $\mathrm{Mo}(\mathrm{V})$. The existence of intermediate $\mathrm{Mo}(\mathrm{V})$, and redox switching of Mo, therefore, faciliated the elctron transfer at this stage, and were essential in functioning of Mo-co containing enzymes, catalyzing certain reactions for carbon, nitrogen, and sulfur cycling since reduced $\mathrm{Mo}(\mathrm{V})$ are essential in $\mathrm{N}_{2}$ fixation (Griffin, 1975; Howarth and Cole, 1985; Yamazaki and Gohda, 1990). Yandulov and Schrock (2003) reported that all reduced species of Mo (+II 


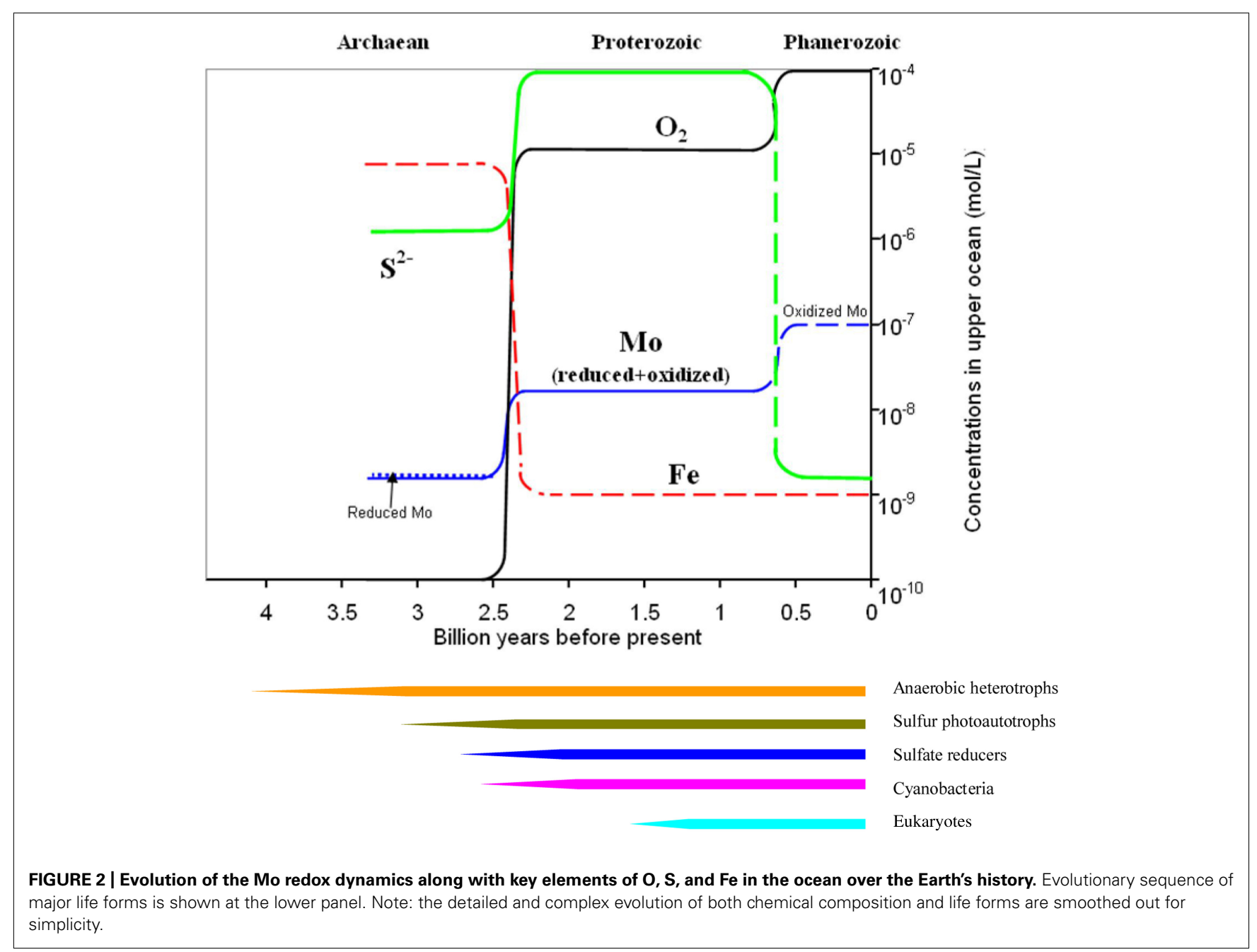

to $+\mathrm{V}$ ) are involved in catalytic reactions of $\mathrm{N}_{2}$ fixation in nitrogenase. As all Mo redox species ( $+\mathrm{II}$ to $+\mathrm{VI}$ ) probably existed in the Archaean ocean, the abundance of $\mathrm{CO}_{2}$ and $\mathrm{N}_{2}$, and lack of $\mathrm{NH}_{4}^{+}$finally prompted the emergence of Mo nitrogenase, which efficiently fixes atmospheric $\mathrm{N}_{2}$ to bioavailable $\mathrm{NH}_{4}^{+}$. In the late Archaean ocean, as the source of electrons for the photosynthesis switched from $\mathrm{HS}^{-}$to $\mathrm{H}_{2} \mathrm{O}$ for increased energy production, photosynthetically produced $\mathrm{O}_{2}$ increased accordingly (e.g., Anbar and Knoll, 2002; Figure 2) until a slight oxygenation of the atmosphere occurred gradually between 2.4 and 2.2 billions years ago (e.g., Farquhar et al., 2000; Kasting and Siefert, 2001; Figure 2).

In the Proterozoic ocean $(2.2 \sim 0.6$ billions years ago $)$, terrestrial input of $\mathrm{SO}_{4}^{2-}$ along with $\mathrm{MoO}_{4}^{2-}$ predominated due to the slightly increased atmospheric $\mathrm{pO}_{2}$ (e.g., Anbar and Knoll, 2002). Paradoxically, sulfate-reducing bacteria also developed, and a sulfidic Proterozoic ocean was, therefore, formed at least near the shelves (e.g., Saito et al., 2003). The redox reactions of Mo between $\mathrm{Mo}(\mathrm{VI})$ and $\mathrm{Mo}(\mathrm{IV})$ at this stage were likely mediated by sulfur photoautotrophs and sulfate reducers (Anderson and Spencer, 1949). With the further increase of atmospheric $\mathrm{pO}_{2}$ in the late Proterozoic, reduced species of Mo were only confined to limited niches including sulfidic waters/sediments and microzones, whilst all oxyanions including nitrate and sulfate became abundant in the ocean. New Mo uptake and storage systems evolved in order to efficiently utilize the ambient molybdate via either high-affinity uptake or less-specific uptake. A series of Mo-co-containing enzymes were newly formed (e.g., Zerkle et al., 2005) to utilize the abundant sulfate and nitrate (e.g., Nicholas et al., 1963; Scott et al., 2008; Wille et al., 2008). New eukaryotes with more efficient molybdate uptake systems (Thiel et al., 2002; Zahalak etal., 2004) and specific storage proteins protecting the sensitive reduced Mo within cytoplasm eventually evolved along with eukaryotes on Earth probably about 1.5-1.0 billion years ago (e.g., Ba et al., 2009).

\section{SUMMARY}

Mo has been considered as one of the most important elements dictating the evolution of life. This mini-review summarized the current findings regarding redox speciation of Mo in natural waters. The contemporary observations of reduced Mo led to the hypothesis that these reduced Mo also existed in the ancient reducing ocean (e.g., in the ferruginous Archaean and sulfidic Proterozoic). The versatile redox chemistry of Mo ranging from 
$+\mathrm{II}$ to $+\mathrm{VI}$ facilitates electron transfer and even oxygen transfer in reactions of carbon, nitrogen, and sulfur in biology. Similarly, redox switching of Mo might be essential in the evolution of Mo enzymes catalyzing different electron and oxygen transfer reactions.

In the ferruginous Archaean, reduced Mo such as $\mathrm{Mo}(\mathrm{V})$ might fundamentally contribute to the metabolic reactions of nitrogen and sulfur by forming nitrogenases and other Mocontaining enzymes. In the sulfidic Proterozoic, redox switching of Mo probably coupled with the sulfur cycling initially. The further increasing of photosynthetically produced $\mathrm{O}_{2}$ constrained reduced Mo only within specific niches including microzones, cytoplasm, and reducing sediments/waters. New eukaryotes with active uptake and storage systems developed in order to utilize oxidized molybdate, and a series of Mo-containing enzymes

\section{REFERENCES}

Aguilar, M., Cardenas, J., and Fernandez, E. (1992). Quantitation of molybdopterin oxidation product in wild-type and molybdenum cofactor deficient mutants of Chlamydomonas reinhardtii. Biochim. Biophys. Acta 1160, 269-274.

Anbar, A. D. (2008). Elements and evolution. Science 322, 1481-1483.

Anbar, A. D., and Knoll, A. H. (2002). Proterozoic ocean chemistry and evolution: a bioinorganic bridge? Science 297, 1137-1142.

Anbar, A. D., Duan, Y., Lyons, T. W., Arnold, G. L., Kendall, B., Creaser, R. A., et al. (2007). A whiff of oxygen before the great oxidation. Science 317, 1903-1906.

Anderson, A. J., and Spencer, D. (1949). Molybdenum and sulphur in symbiotic nitrogen fixation. Nature 164, 273-274.

Ba, L. A., Doering, M., Burkholz, T., and Jacob, C. (2009). Metal trafficking: from maintaining the metal homeostasis to future drug design. Metallomics 1, 292-311.

Barber, M. J., Notton, B. A., and Solomonson, L. P. (1987). Oxidationreduction midpoint potentials of the molybdenum center in spinach NADH:nitrate reductase. FEBS Lett. 213, 372-374.

Barron, A. R., Wurzburger, N., Bellenger, J. P., Wright, S. J., Kraepiel, A. M. L., and Hedin, L. O. (2009). Molybdenum limitation of asymbiotic nitrogen fixation in tropical forest soils. Nat. Geosci. 2, 42-45.

Barton, L. L., Goulhen, F., Bruschi, M., Woodards, N. A., Plunkett, R. M., and Rietmeijer, F. J. M. (2007). The bacterial metallome: composition and stability with specific reference to the anaerobic bacterium Desulfovibrio desulfuricans. Biometals 20, 291-302.
Baxter, I., Muthukumar, B., Park, H. C., Buchner, P., Lahner, B., Danku, J., et al. (2008). Variation in molybdenum content across broadly distributed populations of Arabidopsis thaliana is controlled by a mitochondrial molybdenum transporter (MOT1). PLoS Genet. 4:e1000004. doi: 10.1371/journal.pgen.1000004

Berrang, P. G., and Grill, E. V. (1974). enging on molybdenum in Saanich Inlet, British Columbia. Mar. Chem. 2, 125-148.

Bertine, K. K. (1972). The deposition of molybdenum in anoxic waters. Mar. Chem. 1, 43-53.

Biswas, K. C., Woodards, N. A., Xu, H., and Barton, L. L. (2009). Reduction of molybdate by sulfate-reducing bacteria. Biometals 22, 131-139.

Bittner, F., and Mendel, R. R. (2010). "Cell biology of molybdenum," in Cell Biology of Metals and Nutrients. Plant Cell Monographs, Vol. 17, eds R. Hell and R. R. Mendel (Berlin: Springer-Verlag), 119-143.

Boll, M., Schink, B., Messerschmidt, A., and Kroneck, P. M. H. (2005). Novel bacterial molybdenum and tungsten enzymes: three-dimensional structure, spectroscopy, and reaction mechanism. Biol. Chem. 366, 9991006.

Boyd, P. W., Watson, A. J., Law, C. S., Abraham, E. R., Trull, T., Murdoch, R., etal. (2000). A mesoscale phytoplankton bloom in the polar Southern Ocean stimulated by iron fertilization. Nature 407, 695-702.

Brattberg, G. (1977). Nitrogen fixation in a polluted brackish water archipelago. Ambio Spec. Rep. 5, 27-42.

Brierley, C. L. (1974). Molybdeniteleaching: use of high temperature microbe. J. Less Common Metals 36, 237-247. The effect of manganese oxide scav-

for nitrate assimilation and sulfur detoxification also evolved later on.

\section{ACKNOWLEDGMENTS}

This research was partly supported by the National Science Foundation of China (\#41176060), the National Basic Research Program of China (\#2009CB421204), the Science Foundation of the Fujian Province, China (\#2012J01181), the Specialized Research Fund for the Doctoral Program of Higher Education (20110121120030), the Program for Changjiang Scholars and Innovative Research Team (IRT0941), and the Fundamental Research Funds for the Central Universities in Xiamen University (\#2010121033). I would highly appreciated for the comments and suggestions from the editor and the two reviewers which have greatly improved the quality of the MS.

Brookins, D. G. (1988). Eh-pH Diagrams for Geochemistry. New York: Spring-Verlag, 1-176.

Bryceson, I., and Fay, P. (1981). Nitrogen fixation in Oscillatoria (Trichodesmium) erythraeum in relation to bundle formation and trichome differentiation. Mar. Biol. 61, 159-166.

Burgess, B. K., and Lowe, D. J. (1996). Mechanism of molybdenum nitrogenase. Chem. Rev. 96, 2983-3011.

Burris, R. H. (1991). Nitrogenase, minireview. J. Biol. Chem. 266, 9339 9342.

Butler, C. S., Charnock, J. M., Bennett, B., Sears, H. J., Reilly, A. J., Ferguson, S. J., et al. (1999). Models for molybdenum coordination during the catalytic cycle of periplasmic nitrate reductase from Paracoccus denitrificans derived from EPR and EXAFS spectroscopy. Biochemistry 38, 90009012.

Campbell, W. H. (1999). Nitrate reductase structure, function and regulation: bridging the gap between biochemistry and physiology. Annu. Rev. Plant Physiol. Plant Mol. Biol. 50 , 277-303.

Carpenter, E. J., and Price, C. C. (1976). Marine Oscillatoria (Trichodesmium): explanation for aerobic nitrogen fixation without heterocysts. Science 191, 12781280.

Collier, R. W. (1985). Molybdenum in the northeast Pacific Ocean. Limnol. Oceanogr. 30, 1351-1354.

Coughlan, M. P. (1980). Molybdenum and Molybdenum-containing Enzymes. Oxford: Pergamon Press, $577 \mathrm{p}$.

Cramer, S. P., Gray, H. B., and Rajagopalan, K. V. (1979). The molybdenum site of sulfite oxidase. Structural information from x-ray absorption spectroscopy. J. Am. Chem. Soc. 101, 2772-2774.
Dumont, H. J. (1972). The biological cycle of molybdenum in relation to primary production and water bloom formation in a eutrophic pond. Verh. Int. Ver. Theor. Angew. Limnol. 18, 84-88.

Einsle, O., Tezcan, F. A., Andrade, S. L., Schmid, B., Yoshida, M., Howard, J. B., et al. (2002). Nitrogenase protein at $1.16 \mathrm{~A}$ resolution: a central ligand in the FeMo-cofactor. Science 297, 1696-1700.

Emerson, S. R., and Huested, S. S. (1991). Ocean anoxia and the concentrations of molybdenum and vanadium in seawater. Mar. Chem. 34, 177-196.

Eppley, R. W., Coatsworth, J. L., and Solorzano, L. (1969). Studies of nitrate reductase in marine phytoplankton. Limnol. Oceanogr. 14, 194-205.

ExPASy. (2012). Mo Containing Enzymes. Available at: http://www. expasy.org

Fani, R., and Fondi, M. (2009). Origin and evolution of metabolic pathways. Phys. Life Rev. 6, 23-52.

Farquhar, J., Bao, H., and Thiemans, M. (2000). Atmospheric influence of Earth's earliest sulfur cycle. Science 289, 756-758.

Fenske, D., Gnida, M., Schneider, K., Meyer-Klaucke, W., Schemberg, J., Henschel, V., etal. (2005). A new type of metalloprotein: the Mo storage protein from Azotobacter vinelandii contains a polynuclear molybdenum-oxide cluster. Chembiochem 6, 405-413.

Finkel, Z. V., Quigg, A., Raven, J. A., Reinfelder, J. R., Schofield, O. E., and Falkowski, P. G. (2006). Irradiance and the elemental stoichiometry of marine phytoplankton. Limnol. Oceanogr. 51, 2690-2701.

Garrels, R. M., and Christ, C. L. (1965). Solutions, Minerals, and Equilibria. San Francisco, CA: Freeman, Cooper Co., 1-450. 
Glass, J. B., Axler, R. P., Chandra, S., and Goldman, C. R. (2012). Molybdenum limitation of microbial nitrogen assimilation in aquatic ecosystems and pure cultures. Front. Microbiol. 3:331. doi: 10.3389/fmicb.2012.00331

Glass, J. B., Wolfe-Simon, F., Elser, J. J., and Anbar, A. D. (2010). Molybdenum-nitrogen colimitation in freshwater and coastal heterocystous cyanobacteria. Limnol. Oceanogr. 55, 667-676.

Griffin, M. T. (1975). A Molybdenum (V) Model for Nitrogenase Enzyme. Master's thesis, Texas Tech University, Lubbock.

Gupta, U. C. (1997). "Soil and plant factors affecting molybdenum uptake by plants," in Molybdenum in Agriculture, ed. U. C. Gupta (Cambridge: Cambridge University Press), 71-91.

Helz, G. R., Miller, C. V., Charnock, J. M., Mosselmans, J. F. W., Pattrick, R. A. D., Garner, C. D., et al. (1996). Mechanism of molybdenum removal from the sea and its concentration in black shales: EXAFS evidence. Geochim. Cosmochim. Acta. 60, 3631-3642.

Hernandez, J. A., George, S. J., and Rubio, L. M. (2009). Molybdenum trafficking for nitrogen fixation. Biochemistry 48, 9711-9721.

Heuwinkel, H., Kirkby, E. A., Le Bot, J., and Marschner, H. (1992). Phosphorus deficiency enhances molybdenum uptake by tomato plants. $J$. Plant Nutr. 15, 549-568.

Hewitt, E. J., and Bolle-Jones, E. W. (1952). Molybdenum as a plant nutrient. II. The effects of molybdenum deficiency on some horticultural and agricultural crop plants in sand culture. J. Hortic. Sci. 27, 257-265.

Hille, R. (1996). The mononuclear molybdenum enzymes. Chem. Rev. 96, 2757-2816.

Hille, R. (1999). "Molybdenum enzymes," in Essays in Biochemistry: Metalloproteins, ed. S. J. Higgins (Princeton, NJ: Princeton University Press), 125-138.

Hille, R. (2002). Molybdenum and tungsten in biology. Trends Biochem. Sci. 27, 360-366.

Hille, R., and Massey, V. (1985). "Molybdenum-containing hydroxylases: xanthine oxidase, aldehyde oxidase, and sulfite oxidase," in Molybdenum Enzymes, ed. T. G. Spiro (New York: John Wiley \& Sons), 443-518.

Ho, T. Y., Quigg, A., Finkel, Z. V., Milligan, A. J., Wyman, K., Falkowski, P. G., etal. (2003). The elemental composition of some marine phytoplankton. J. Phycol. 39, 1145-1159.

Howard, J. B., and Rees, D. C. (1996). Structural basis of biological nitrogen fixation. Chem. Rev. 96, 2965-2982.

Howarth, R. W., and Cole, J. J. (1985). Molybdenum availability, nitrogen limitation, and phytoplankton growth in natural waters. Science 229, 653-655.

Hu, Y., Fay, A. W., Lee, C. C., Yoshizawa, J., and Ribbe, M. W. (2008). Assembly of nitrogenase MoFe protein. Biochemistry 47, 3973-3981.

Ichimori, K., Fukahori, M., and Nakazawa, H. (1999). Inhibition of xanthine oxidase and xanthine dehydrogenase by nitric oxide. J. Biol. Chem. 274, 7763-7768.

Kaiser, B. N., Gridley, K. L., Brady, J. N., Phillips, T., and Tyerman, S. D. (2005). The role of molybdenum in agricultural plant production. Ann. Bot. 96, 745-754.

Kasting, J. F., and Siefert, J. L. (2001). The nitrogen fix. Nature 412, 26-27.

Kisker, C., Schindelin, H., and Rees, D. C. (1997). Molybdenum-cofactorcontaining enzymes: structure and mechanism. Annu. Rev. Biochem. 66 233-267.

Kisker, C., Schindelin, H., Baas, D., Rétey, J., Meckenstock, R. U., and Kroneck, P. M. H. (1999). A structural comparison of molybdenum cofactor-containing enzymes. FEMS Microbiol. Rev. 22, 503-521.

Kroneck, P. M. H., and Abt, D. J. (2002). Molybdenum in nitrate reductase and nitrite oxidoreductase. Met. Ions Biol. Syst. 39, 369-403.

Liermann, L., Guynn, R. L., Anbar, A., and Brantley, S. L. (2005). Production of a molybdophore during metal-targeted dissolution of silicates by soil bacteria. Chem. Geol. 220, 285-302.

Lippard, S. J., Berg, J. M., and Klatt, G. (1994). Principles of Bioinorganic Chemistry. Mill Valley, CA: University Science Books, 411 p.

Loach, P. A. (1970). "Oxidationreduction potentials, absorbance bands and molar absorbance of compounds used in biochemical studies," in Handbook of Biochemistry: Selected Data for Molecular Biology, 2nd Edn, ed H. A. Sober (Cleveland, OH: The Chemical Rubber Co.), 1-34.

Lyalikova, N. N., and Lebedeva, E. V. (1984). Bacterial oxidation of molybdenum in ore deposits. Geomicrobiol. J. 3, 307-218.

Magalon, A., Fedor, J. G., Walburger, A. and Weiner, J. H. (2011). Molybdenum enzymes in bacteria and their maturation. Coord. Chem. Rev. 255, 1159-1178.
Marschner, H. (1995). Mineral Nutrition in Higher Plants. London: Academic Press.

Martin, J. H., and Fitzwater, S. E. (1988). Iron deficiency limits phytoplankton growth in the north-east Pacific subarctic. Nature 331, 341-343.

Martin, J. M., and Meyback, M. (1979). Elemental mass-balance of material carried by major world rivers. Mar Chem. 7, 173-206.

Massey, V., Komai, H., Palmer, G., and Elion, G. B. (1970). On the mechanism of inactivation of xanthine oxidase by allopurinol and other pyrazolo[3,4-d]pyrimidines. J. Biol. Chem. 245, 6595-6598.

McMaster, J., and Enemark, J. H. (1998). The active sites of molybdenum and tungsten enzymes. Curr. Opin. Chem. Biol. 2, 201-207.

Mendel, R. R. (2005). Molybdenum: biological activity and metabolism. Dalton Trans. 3404-3409.

Mendel, R. R., and Bittner, F. (2006). Cell biology of molybdenum. Biochim. Biophys. Acta 1763, 621-635.

Mendel, R. R., and Schwarz, G. (2011). Molybdenum cofactor biosynthesi in plants and humans. Coordin. Chem. Rev. 255, 1145-1158.

Miller, K. F., Bruce, A. E., Corbin, J. L., Wherland, S., and Stiefel, E. I. (1980). $\mathrm{Mo}_{2} \mathrm{~S}_{4}^{2+}$ core: new syntheses, new complexes, and electrochemical diversity. J. Am. Chem. Soc. 102, 5102-5104.

Morozkina, E. V., and Zvyagilskaya, R. A. (2007). Nitrate reductases: structure, functions, and effect of stress factors. Biochemistry 72, 11511160.

NC-IUB. (2012). Nomenclature of Electron-transfer Proteins: Section 6-12. Available at: http://www.chem.qmul. ac.uk/iubmb/etp/etp6t11.html

Nicholas, D. J. D., Redmond, W. J., and Wright M. A. (1963). Molybdenum and iron requirements for nitrate reductase in Photobacterium sepia. Nature 200, 1125-1126.

Nisbet, E. (2000). The realms of Archaean life. Nature 405, 625-626.

Paerl, H. W., and Bland, P. T. (1982). Localised tetrazolium reduction in relation to $\mathrm{N}_{2}$ fixation, $\mathrm{CO}_{2}$ fixation, and $\mathrm{H}_{2}$ uptake in aquatic filamentous cyanobacteria. Appl. Environ. Microbiol. 43, 218-226.

Paerl, H. W. (1985). Microzone formation: its role in the enhancement of aquatic $\mathrm{N}_{2}$ fixation. Limnol. Oceanogr. 30, 1246-1252.

Paerl, H. W., and Prufert, L. E. (1987) Oxygen-poor microzones as potential sites of microbial $\mathrm{N}_{2}$ fixation in nitrogen-depleted aerobic marine waters. Appl. Environ. Microbiol. 53, 1078-1087.

Paerl, H. W., Crocker, K. M., and Prufert, L. E. (1987). Limitation of $\mathrm{N}_{2}$ fixation in coastal marine waters: relative importance of molybdenum, iron, phosphorus, and organic matter availability. Limnol. Oceanogr. 32, 525-536.

Pau, R. N., and Lawson, D. M. (2002). Transport, homeostasis, regulation, and binding of molybdate and tungstate to proteins. Met. Ions Biol. Syst. 39, 31-74.

Paulsen, D. M., Paerl, H. W., and Bishop, P. E. (1991). Evidence that molybdenum-dependent nitrogen fixation is not limited by high sulfate concentrations in marine environments. Limnol. Oceanogr. 36, 1325-1334.

Ploug, H., Kühl, M., Buchholz-Cleven, B., and Jørgensen, B. B. (1997). Anoxic aggregates-an ephemeral phenomenon in the pelagic environment? Aquat. Microb. Ecol. 13, 285-294.

Rajagopalan, K. V., and Johnson, J. L. (1992). The pterin molybdenum cofactors. J. Biol. Chem. 267, 1019910202.

Romero, I. C., Klein, N. J., Barada, L., Vo, J., Liss, A. M., Cutter, L., et al. (2011). "Trace metal co-limitation controls on nitrogen fixation in lakes with varying trophic status," in ASLO Aquatic Sciences Meeting, San Juan, Puerto Rico.

Saito, M. A., Sigman, D. M., and Morel, F. M. M. (2003). The bioinorganic chemistry of the ancient ocean: the co-evolution of cyanobacterial metal requirements and biogeochemical cycles at the Archean/Proterozoic boundary? Inorganica Chim. Acta 356, 308-318.

Schemberg, J., Schneider, K., Fenske, D., and Müller, A. (2008). Azotobacter vinelandii metal storage protein: "classical" inorganic chemistry involved in Mo/W uptake and release processes. Chembiochem 9, 595-602.

Scott, C., Lyons, T. W., Bekker, A., Shen, Y., Poulton, S. W., Chu, X., etal. (2008). Tracing the stepwise oxygenation of the Proterozoic ocean. Nature 452, 456-459.

Spriro, T. G. (1985). Molybdenum Enzymes. New York: John Wiley \& Sons.

Stiefel, E. I. (1997). Chemical keys to molybdenum enzymes. Dalton Trans. 1997, 3915-3923.

Stiefel, E. I. (1993). "Molybdenum enzymes, cofactors, and chemistry: an introductory survey," in Molybdenum Enzymes, Cofactors, and Model Systems, ACS Symposium Series 535, 
eds E. I. Stiefel, D. Coucouvanis, and W. E. Newton (Washington DC: American Chemical Society), $1-19$.

Stiefel, E. I. (1998). Transition metal sulfur chemistry and its relevance to molybdenum and tungsten enzymes. Pure Appl. Chem. 70, 889-896.

Sugio, T., Hirayama, K., Inagaki, K., Tanaka, H., and Tano, T. (1992). Molybdenum oxidation by Thiobacillus ferrooxidans. Appl. Environ. Microbiol. 58, 1768-1771.

Swedo, K. B., and Enemark, J. H. (1979). Some aspects of the bioinorganic chemistry of molybdenum. J. Chem. Educ. 56, 70-76.

Szilágyi, M. (1967). Sorption of molybdenum by humus preparations. Geochem. Int. 4, 1165-1167.

Tejada-Jimenez, M., Llamas, A., SanzLuque, E., Galvan, A., and Fernandez, E. (2007). A high-affinity molybdate transporter in eukaryotes. Proc. Natl. Acad. Sci. U.S.A. 104, 20126 20130.

Thiel, T., Pratte, B., and Zahalak, M. (2002). Transport of molybdate in the cyanobacterium Anabaena variabilis ATCC 29413. Arch. Microbiol. 179, 50-56.

Tomatsu, H., Takano, J., Takahashi, H., Watanabe-Takahashi, A., Shibagaki, N., and Fujiwara, T. (2007). An Arabidopsis thaliana high-affinity molybdate transporter required for efficient uptake of molybdate from soil. Proc. Natl. Acad. Sci. U.S.A. 104, 18807-18812.

Tucker, M. D., Barton, L. L., and Thomson, B. M. (1997). Reduction and immobilization of molybdenum by Desulfovibrio desulfuricans. J. Environ. Qual. 26, 1146-1152.

Tucker, M. D., Barton, L. L., and Thomson, B. M. (1998). Reduction of Cr, Mo, Se and U by Desulfovibrio desulfuricans immobilized in polyacrylamide gels. J. Ind. Microbiol. Biotechnol. 20, 13-19.

Turner, D. R., Whitfiled, M., and Dickson, A. G. (1981). The equilibrium speciation of dissolved components in freshwater and seawater at $25^{\circ} \mathrm{C}$ and 1 atm pressure. Geochim. Cosmochim. Acta 45, 855-881.

Tweedie, J. W., and Segel, I. H (1970). Specificity of transport processes for sulfur, selenium, and molybdenum anions by filamentous fungi. Biochim. Biophys. Acta 196, 95-106.

Vorlicek, T. P., and Helz, G. R. (2002). Catalysis by mineral surfaces: implications for Mo geochemistry in anoxic environments. Geochim. Cosmochim. Acta 66, 2197 3692.

Wang, D., Aller, R. C., and SañudoWilhelmy, S. A. (2009). A new method for the quantification of different redox-species of molybdenum (V and VI) in seawater. Mar. Chem. $113,250-256$.
Wang, D., Aller, R. C., and Sañudo-Wilhelmy, S. A. (2011). Redox speciation and early diagenetic behavior of dissolved molybdenum in sulfidic muds. Mar. Chem. 125 101-107.

Wedepohl, K. H. (1995). The composition of the crust. Geochim. Cosmochim. Acta 59, 1217-1232.

Wille, M., Nägler, T. F., Lehmann, B. Schröder, S., and Kramers, S. D. (2008). Hydrogen sulphide release to surface waters at the Precambrian/Cambrian boundary. Nature 453, 767-769.

Williams, R. J. P., and Fraústo da Silva, J. J. R. (2002). The involvement of molybdenum in life. Biochem. Biophys. Res. Commun. 292, 293-299.

Yamazaki, H., and Gohda, S. (1990). Distribution of dissolved molybdenum in the Seto Inland Sea, the Japan Sea, the Bering Sea and the Northwest Pacific Ocean. Geochem. J. 24, 273-281.

Yandulov, D. V., and Schrock, R. R. (2003). Catalytic reduction of dinitrogen to ammonia at a single molybdenum center. Science 301, 76-78.

Zahalak, M., Pratte, B., Werth, K. J., and Thiel, T. (2004). Molybdate transport and its effect on nitrogen utilization in the cyanobacterium Anabaena variabilis ATCC 29413. Mol. Microbiol. 51, 539-549.

Zerkle, A. L., House, C. H., and Brantley, S. L. (2005). Biogeochemical signatures through time as inferred from whole microbial genomes. Am. J. Sci. 305, 467-502.

Zhang, Y., and Gladyshev, V. N. (2008). Molybdoproteomes and evolution of molybdenum utilization. J. Mol. Biol. $379,881-899$.

Conflict of Interest Statement: The author declares that the research was conducted in the absence of any commercial or financial relationships that could be construed as a potential conflict of interest.

Received: 30 September 2012; accepted: 03 December 2012; published online: 21 December 2012.

Citation: Wang D (2012) Redox chemistry of molybdenum in natural waters and its involvement in biological evolution. Front. Microbio. 3:427. doi: 10.3389/fmicb.2012.00427

This article was submitted to Frontiers in Aquatic Microbiology, a specialty of Frontiers in Microbiology.

Copyright (C) 2012 Wang. This is an openaccess article distributed under the terms of the Creative Commons Attribution License, which permits use, distribution and reproduction in other forums, provided the original authors and source are credited and subject to any copyright notices concerning any third-party graphics etc. 